\title{
DNA-DNA hybridization study of Burkholderia species using genomic DNA macro-array analysis coupled to reverse genome probing
}

\author{
Vincent Ramisse, ${ }^{1}$ Jacques Balandreau, ${ }^{2}$ François Thibault, ${ }^{3}$ \\ Dominique Vidal, ${ }^{3}$ Gilles Vergnaud ${ }^{1}$ and Philippe Normand ${ }^{2}$ \\ ${ }^{1}$ Centre d'Etudes du Bouchet (CEB), BP3, 91710 Vert le Petit, France
2Écologie Microbienne, UMR 5557 CNRS, Bât. 741, Université Claude Bernard Lyon I, 69622 Villeurbanne cedex, France
${ }^{3}$ Centre de Recherches du Service de Santé des Armées, BP87, 38702 La Tronche cedex, France

Correspondence

Vincent Ramisse

vramisse@ceb.etca.fr

\begin{abstract}
The present study was aimed at simplifying procedures to delineate species and identify isolates based on DNA-DNA reassociation. DNA macro-arrays harbouring genomic DNA of reference strains of several Burkholderia species were produced. Labelled genomic DNA, hybridized to such an array, allowed multiple relative pairwise comparisons. Based on the relative DNA-DNA relatedness values, a complete data matrix was constructed and the ability of the method to discriminate strains belonging to different species was assessed. This simple approach led successfully to the discrimination of Burkholderia mallei from Burkholderia pseudomallei, but also discriminated Burkholderia cepacia genomovars I and III, Burkholderia multivorans, Burkholderia pyrrocinia, Burkholderia stabilis and Burkholderia vietnamiensis. Present data showed a sufficient degree of congruence with previous DNA-DNA reassociation techniques. As part of a polyphasic taxonomic scheme, this straightforward approach is proposed to improve species definition, especially for application in the rapid screening necessary for large numbers of clinical or environmental isolates.
\end{abstract}

The genus Burkholderia, formerly Pseudomonas homology group II (Yabuuchi et al., 1992), comprises 29 validly published species at the time of writing. It includes soil and rhizosphere bacteria, as well as plant and human pathogens (Gilligan, 1995). Among them are several species of particular interest in clinical microbiology. A review on Burkholderia taxonomy is available (Coenye et al., 2001c).

Burkholderia pseudomallei, the causative agent of melioidosis in humans, is a natural saprophytic micro-organism present in soils and stagnant waters in tropical regions (Dance, 2002). The ability of this species to invade and survive within free-living amoebae might affect its environmental survival and subsequent human exposure (Inglis et al., 2000). Melioidosis is transmitted by contact with contaminated soil or water through skin wounds, ingestion or inhalation (Benenson, 1995). Burkholderia mallei is

Published online ahead of print on 19 September 2002 as DOI 10.1099/ijs.0.02483-0.

Abbreviations: CF, cystic fibrosis; MF, microfluorimetry; NS1, nuclease $\mathrm{S} 1 ; R$, hybridization signal ratio; $\mathrm{SP}$, spectrophotometry.

The EMBL/GenBank accession number for the $16 \mathrm{~S}$ rRNA gene sequence of CEB 01056 is AJ491304. responsible for glanders, a highly communicable disease of horses that is transmissible to humans (Benenson, 1995). This disease no longer occurs in the Western hemisphere, except for sporadic occupational cases (Srinivasan et al., 2001). Both B. pseudomallei and B. mallei are potential biological warfare and terrorism agents that necessitate efforts for preparedness, including rapid and accurate diagnostics (Rotz et al., 2002).

A major outcome of recent taxonomic studies of this genus has been the division of the Burkholderia cepacia complex into at least nine discrete genomic species, genomovars I-IX (Coenye et al., 2001a, b; Vandamme et al., 1997, 2000, 2002) that inhabit major environmental reservoirs but are frequently involved in nosocomial infections in patients with cystic fibrosis (CF) and other vulnerable individuals (Heath et al., 2002; Speert et al., 2002). B. cepacia complex infections contribute significantly to morbidity and mortality in CF patients. By 18 years of age, $80 \%$ of patients harbour Pseudomonas aeruginosa and 3.5\% harbour B. cepacia (Rajan \& Saiman, 2002). A study of 905 isolates from the B. cepacia complex recovered from $447 \mathrm{CF}$ patients in Canada confirmed the prevalence of B. cepacia genomovar III $(80 \%)$, Burkholderia multivorans (formerly 
genomovar II) (10\%) and other genomovars of the B. cepacia complex or other Burkholderia species (9\%) (Speert et al., 2002). On the other hand, B. cepacia genomovar III is a common plant-associated bacterium (Balandreau et al., 2001). Moreover, human-pathogenic strains may not necessarily be distinct from environmental strains (LiPuma et al., 2002). There is some evidence that the health risks associated with infection are dependent on the nature of the genomovar, so the ability to differentiate genomovars is important for clinical microbiologists (Brisse et al., 2000; Henry et al., 2001; Mahenthiralingam et al., 2000). The accurate diagnosis of Burkholderia isolates is a challenge for the prevention and control of microbial infection caused by opportunistic pathogens. Moreover, the agricultural use of B. cepacia as a biopesticide for protecting crops against fungal diseases and as a bioremediation agent for decontamination of remanent pesticides is the subject of controversy (Holmes et al., 1998; Jones et al., 2001). The risks of the biotechnological uses of the $B$. cepacia complex and the ecology of the bacteria have been reviewed by Parke \& Gurian-Sherman (2001).

Commercial bacterial identification systems are not always able to determine the genomovar status, nor accurately confirm the identification of $B$. cepacia isolates while differentiating them from closely related species. We have also observed ambiguous identification of some isolates of B. mallei and B. pseudomallei, thus rendering PCR- or antibody-based procedures valuable to confirm species identification (Bauernfeind et al., 1998; Steinmetz et al., 1999). A combination of phenotypic and molecular tests are recommended for differentiation among the genomovars of the B. cepacia complex (Henry et al., 2001). Nucleotide sequence variation within $16 \mathrm{~S} \mathrm{rDNA}$ is not sufficient to enable all genomovars to be discriminated by RFLP (Segonds et al., 1999). Nucleotide sequence analysis of the orthologous single-copy gene $r e c A$ provides a means of identifying the current genomovars and newly delineated species within the B. cepacia complex (Mahenthiralingam et al., 2000), but single-locus-based identification schemes are risky because of the prevalence of lateral transfer (Mougel et al., 2002; Ochman et al., 2000).

The determination of the DNA-DNA relatedness of the whole genome remains an irreplaceable step in the delineation of bacterial species (Stackebrandt et al., 2002; Wayne et al., 1987). Nevertheless, there is a strong tendency to replace it because DNA-DNA reassociation experiments are not easily carried out, even though numerous methods with simplified and more reproducible steps have been described (Johnson, 1991). Moreover, the polyphasic taxonomic approach fulfils taxonomists' requirements by studying a wide range of genotypic and phenotypic information, but makes the identification procedure more complex (Rosselló-Mora \& Amann, 2001; Vandamme et al., 1996). Developments in the field of high-density DNA arrays show great promise for bacterial systematics (Stackebrandt et al., 2002), but there is no routinely available application at present. As it is not easy for any laboratory to invest the efforts required to ensure a polyphasic approach for bacterial identification, and considering that species definition should still be based on determination of DNA-DNA relatedness, we felt the necessity to return to this approach but in a more simple manner. Here, we report a prospective work concerning a simplified way to implement species delineation, based on whole genomic DNA-DNA hybridization using DNA macro-arrays. This paper describes the method and its evaluation with previously characterized strains of the genus Burkholderia.

DNA macro-arrays were constructed from DNA extracted, as described by Yabuuchi et al. (1992), from reference strains of the Burkholderia species listed in Table 1. Burkholderia sp. CEB 01056, isolated in Centre d'Etudes du Bouchet (CEB) as a laboratory contaminant, was included in the study in an attempt to clarify its identification. The almost-complete 16S rDNA sequence (GenBank no. AJ491304) suggests that this isolate is closely related to the members of the B. cepacia complex, with similarity values ranging from $98 \cdot 6$ to $99 \cdot 7 \%$. Staphylococcus epidermidis (an environmental isolate, CEB 01074) was used as an outgroup. A DNA macro-array consisted of a $18 \times 18 \mathrm{~mm}$ square of positively charged nylon transfer membrane Hybond-N+ (Amersham Biosciences) onto which 15 different alkali-denaturated genomic DNAs (250 ng DNA in $10 \mu \mathrm{l} 200 \mathrm{mM} \mathrm{NaOH}$, $30 \mu \mathrm{M}$ bromophenol blue per dot) and a blank (all reagents but no DNA) were spotted using the Hydra-96 Microdispenser coupled to its vacuum manifold (Robbins Scientific). Dots were $2 \mathrm{~mm}$ in diameter. Macro-arrays were produced in 10 batches, each consisting of 24 membranes (240 macro-arrays in total). Genomic DNA (100 ng) from all the strains listed (Table 1) was labelled, in a final volume of $20 \mu \mathrm{l}$, using $370 \mathrm{kBq}\left[\alpha^{-{ }^{32}} \mathrm{P}\right] \mathrm{dCTP}\left(110 \mathrm{TBq} \mathrm{mmol}^{-1}\right.$; Amersham Biosciences) and the Random Primed DNA Labeling kit (Roche Diagnostics), according to the manufacturer's instructions. Unincorporated nucleotides were removed by Sephadex G-50 filtration with the Multiscreen separation system MAHV-N45 (Amersham Biosciences) according to the manufacturer's instructions. Based on the observed mean of the incorporation rate $(>50 \%)$ and on the rate of DNA recovery after filtration $(>65 \%)$, the procedure routinely gives $>65 \mathrm{ng}$ labelled DNA with a specific activity of $2 \mathrm{MBq} \mu \mathrm{g}^{-1}$. Individual hybridization chambers consisted of $1.8 \mathrm{ml}$ Nunc CryoTube vials (Nalge Nunc International) into which a DNA macro-array was introduced and allowed to pre-hybridize for $2 \mathrm{~h}$ at $65^{\circ} \mathrm{C}$ under agitation (8 rotations min $^{-1}$ ) with $500 \mu$ l Rapid-hyb buffer (Amersham Biosciences) before introduction of the purified probe $(20 \mu \mathrm{l})$ and overnight hybridization under the same conditions. Free labelled DNA was removed by successive washing steps at $65^{\circ} \mathrm{C}$ with $2 \times$ SSC, $0 \cdot 1 \%$ SDS then $0 \cdot 1 \times$ SSC, $0 \cdot 1 \%$ SDS washing buffer (Amresco). DNA macro-arrays were scanned at $100 \mu \mathrm{m}$ resolution using the Molecular Imager system GS-525 (Bio-Rad). For each DNA macro-array hybridized with a given labelled DNA, DNADNA relatedness was expressed as the hybridization signal 
Table 1. DNA homology as determined by DNA macro-array analysis among 13 Burkholderia strains

Strains: 1, B. cepacia (I) ATCC $25416^{\mathrm{T}}$; 2, B. cepacia (III) LMG 12614; 3, B. multivorans (II) LMG $13010^{\mathrm{T}}$; 4, B. pyrrocinia ATCC 15958 $8^{\mathrm{T}}$; 5, B. stabilis (IV) LMG $14294^{\mathrm{T}}$; 6, B. vietnamiensis (V) LMG 10929 ${ }^{\mathrm{T}}$; 7, Burkholderia sp. CEB 01056; 8, B. caribensis LMG $18531^{\mathrm{T}}$; 9, B. gladioli ATCC $10248^{\mathrm{T}}$; 10, B. glathei ATCC 29195 ${ }^{\mathrm{T}}$;1, B. plantarii LMG $9035^{\mathrm{T}}$; 12, B. mallei ATCC $23344^{\mathrm{T}}$; 13, B. pseudomallei ATCC 23343 $3^{\mathrm{T}}$; 14, S. epidermidis CEB 01074; 15, S. epidermidis CEB 01074 (duplicate); 16, No DNA. Strains were obtained from ATCC (American Type Culture Collection), Manassas, VA, USA; LMG (Culture Collection of Laboratorium voor Microbiologie), State University of Ghent, Ghent, Belgium; CEB (Culture Collection of Centre d'Etudes du Bouchet), Vert le Petit, France.

\begin{tabular}{|c|c|c|c|c|c|c|c|c|c|c|c|c|c|c|}
\hline \multirow{2}{*}{$\begin{array}{l}\text { DNA } \\
\text { on } \\
\text { arrays }\end{array}$} & \multicolumn{14}{|c|}{ R $(\%)^{*}$ with labelled DNA (100 $\mathrm{ng}$ ) from: } \\
\hline & $\begin{array}{c}1 \\
(n=4)\end{array}$ & $\begin{array}{c}2 \\
(n=4)\end{array}$ & $\begin{array}{c}3 \\
(n=4)\end{array}$ & $\begin{array}{c}4 \\
(n=4)\end{array}$ & $\begin{array}{c}5 \\
(n=4)\end{array}$ & $\begin{array}{c}6 \\
(n=4)\end{array}$ & $\begin{array}{c}7 \\
(n=4)\end{array}$ & $\begin{array}{c}8 \\
(n=4)\end{array}$ & $\begin{array}{c}9 \\
(n=5)\end{array}$ & $\begin{array}{c}10 \\
(n=4)\end{array}$ & $\begin{array}{c}11 \\
(n=4)\end{array}$ & $\begin{array}{c}12 \\
(n=15)\end{array}$ & $\begin{array}{c}13 \\
(n=3)\end{array}$ & $\begin{array}{c}14 \\
(n=8)\end{array}$ \\
\hline 1 & $54 \cdot 00 \pm 3 \cdot 90$ & $12 \cdot 29 \pm 2 \cdot 03$ & $8 \cdot 06 \pm 0.71$ & $14 \cdot 63 \pm 4 \cdot 16$ & $11 \cdot 12 \pm 1 \cdot 97$ & $6 \cdot 13 \pm 2 \cdot 87$ & $10 \cdot 59 \pm 1.92$ & $2 \cdot 33 \pm 1 \cdot 34$ & $2 \cdot 72 \pm 1 \cdot 15$ & $2 \cdot 00 \pm 0 \cdot 24$ & $8 \cdot 19 \pm 1 \cdot 91$ & $6 \cdot 90 \pm 2 \cdot 29$ & $5 \cdot 20 \pm 1 \cdot 64$ & $0 \cdot 18 \pm 0 \cdot 07$ \\
\hline 2 & $7 \cdot 53 \pm 1 \cdot 86$ & $41 \cdot 23 \pm 7 \cdot 43$ & $5 \cdot 77 \pm 1 \cdot 27$ & $7 \cdot 98 \pm 2 \cdot 17$ & $6 \cdot 00 \pm 1 \cdot 87$ & $4.93 \pm 2.05$ & $5 \cdot 46 \pm 1 \cdot 91$ & $2 \cdot 08 \pm 0 \cdot 78$ & $1 \cdot 58 \pm 0.46$ & $1 \cdot 29 \pm$ & $5 \cdot 16 \pm$ & $4 \cdot 22 \pm 1 \cdot 06$ & $3 \cdot 14$ & $\cdot 47$ \\
\hline 3 & $4 \cdot 88 \pm 0 \cdot 47$ & $6 \cdot 69 \pm 1 \cdot 15$ & $44 \cdot 99 \pm 7 \cdot 26$ & $5 \cdot 82 \pm 1 \cdot 24$ & $4 \cdot 12 \pm 1 \cdot 29$ & $3 \cdot 77 \pm 2 \cdot 43$ & $5 \cdot 92 \pm 0 \cdot 89$ & $2 \cdot 02 \pm 1 \cdot 14$ & $2 \cdot 28 \pm 1 \cdot 25$ & $2 \cdot 09 \pm 0 \cdot 57$ & $7 \cdot 30 \pm 1 \cdot 84$ & $6 \cdot 03 \pm 1 \cdot 43$ & $4 \cdot 44 \pm 1 \cdot 88$ & $0 \cdot 74 \pm 0 \cdot 23$ \\
\hline 4 & $6 \cdot 07 \pm 1 \cdot 89$ & $6 \cdot 69 \pm 1 \cdot 48$ & $7 \cdot 87 \pm 3 \cdot 70$ & $40 \cdot 12 \pm 8 \cdot 90$ & $6 \cdot 24 \pm 0 \cdot 52$ & $4 \cdot 74 \pm 0 \cdot 88$ & $5 \cdot 45 \pm 0 \cdot 78$ & $1 \cdot 23 \pm 0 \cdot 99$ & $1.65 \pm 1.09$ & $1 \cdot 07 \pm 0.67$ & $4 \cdot 03 \pm 2 \cdot 55$ & $3 \cdot 47 \pm 1 \cdot 10$ & $2 \cdot 74 \pm 1 \cdot 25$ & $0 \cdot 17 \pm 0 \cdot 05$ \\
\hline 5 & $8 \cdot 22 \pm 0 \cdot 73$ & $9 \cdot 51 \pm 2 \cdot 33$ & $8 \cdot 42 \pm 1 \cdot 40$ & $10 \cdot 15 \pm 2 \cdot 26$ & $57 \cdot 66 \pm 3 \cdot 35$ & $3 \cdot 69 \pm 2 \cdot 48$ & $8 \cdot 21 \pm 2 \cdot 01$ & $1.66 \pm 1.35$ & $2 \cdot 53 \pm 1 \cdot 50$ & $1 \cdot 01 \pm 0 \cdot 44$ & $5 \cdot 97 \pm 2 \cdot 01$ & $6 \cdot 03 \pm 2 \cdot 28$ & $4 \cdot 30 \pm 2 \cdot 32$ & $0 \cdot 31 \pm 0 \cdot 13$ \\
\hline 6 & $6 \cdot 40 \pm 1 \cdot 96$ & $8 \cdot 38 \pm 3 \cdot 41$ & $7 \cdot 61 \pm 4 \cdot 54$ & $6 \cdot 04 \pm 0 \cdot 71$ & $4 \cdot 47 \pm 0 \cdot 86$ & $56 \cdot 69 \pm 6 \cdot 58$ & $9 \cdot 01 \pm 3 \cdot 70$ & $2 \cdot 25 \pm 1 \cdot 86$ & $2 \cdot 66 \pm 1.98$ & $1 \cdot 62 \pm 1 \cdot 11$ & $9 \cdot 59 \pm 7 \cdot 27$ & $9 \cdot 89 \pm 4 \cdot 77$ & $5 \cdot 30 \pm 2 \cdot 97$ & $0 \cdot 47 \pm 0 \cdot 29$ \\
\hline 7 & $6 \cdot 04 \pm 1 \cdot 57$ & $6 \cdot 79 \pm 1 \cdot 64$ & $5 \cdot 97 \pm 1 \cdot 10$ & $7 \cdot 94 \pm 2 \cdot 89$ & $4 \cdot 79 \pm 1 \cdot 64$ & $5 \cdot 98 \pm 2 \cdot 82$ & $46 \cdot 29 \pm 7 \cdot 16$ & $1 \cdot 90 \pm 0 \cdot 70$ & $2 \cdot 33 \pm 0 \cdot 84$ & $1 \cdot 83 \pm 0 \cdot 86$ & $4 \cdot 97 \pm 1 \cdot 05$ & $3 \cdot 65 \pm 0 \cdot 90$ & $3 \cdot 67 \pm 2 \cdot 14$ & $0 \cdot 13 \pm 0 \cdot 04$ \\
\hline 8 & $0 \cdot 98 \pm 0 \cdot 22$ & $1 \cdot 41 \pm 0.58$ & $1.72 \pm 1 \cdot 01$ & $1.06 \pm 0.39$ & $0.72 \pm 0.03$ & $1 \cdot 16 \pm 0 \cdot 29$ & $1 \cdot 58 \pm 0 \cdot 22$ & $79 \cdot 72 \pm 11 \cdot 17$ & $1 \cdot 33 \pm 0.55$ & $1.73 \pm 0.54$ & $2 \cdot 84 \pm 0 \cdot 86$ & $1 \cdot 87 \pm 0 \cdot 82$ & $1 \cdot 61 \pm 0 \cdot 74$ & $0.21 \pm 0.06$ \\
\hline 9 & $1.56 \pm 0.53$ & $1 \cdot 76 \pm 0.53$ & $2 \cdot 52 \pm 0 \cdot 32$ & $1.68 \pm 0.88$ & $1 \cdot 11 \pm 0 \cdot 24$ & $1 \cdot 85 \pm 0 \cdot 46$ & $2 \cdot 32 \pm 0 \cdot 44$ & $1 \cdot 83 \pm 0 \cdot 86$ & $75 \cdot 77 \pm 12 \cdot 10$ & $1.66 \pm 0.54$ & $12 \cdot 70 \pm 2 \cdot 45$ & $3 \cdot 05 \pm 1 \cdot 26$ & $2 \cdot 65 \pm 1 \cdot 76$ & $0.08 \pm 0.02$ \\
\hline 10 & $1 \cdot 17 \pm 0 \cdot 72$ & $1 \cdot 31 \pm 0 \cdot 78$ & $1 \cdot 49 \pm 0 \cdot 58$ & $1 \cdot 23 \pm 0 \cdot 80$ & $0.84 \pm 0.41$ & $1 \cdot 21 \pm 0 \cdot 82$ & $1 \cdot 60 \pm 0 \cdot 88$ & $2 \cdot 40 \pm 1 \cdot 01$ & $2 \cdot 33 \pm 1 \cdot 64$ & $81 \cdot 74 \pm 4 \cdot 10$ & $3 \cdot 37 \pm 0 \cdot 81$ & $3 \cdot 75 \pm 1 \cdot 68$ & $2 \cdot 55 \pm 1 \cdot 25$ & $0 \cdot 40 \pm 0 \cdot 44$ \\
\hline 11 & $0 \cdot 42 \pm 0 \cdot 08$ & $0 \cdot 47 \pm 0 \cdot 08$ & $0 \cdot 87 \pm 0 \cdot 21$ & $0 \cdot 46 \pm 0.08$ & $0.53 \pm 0.09$ & $0.83 \pm 0.39$ & $0 \cdot 46 \pm 0.09$ & $0 \cdot 49 \pm 0 \cdot 42$ & $1 \cdot 87 \pm 0 \cdot 32$ & $0 \cdot 49 \pm 0 \cdot 13$ & $27 \cdot 89 \pm 15 \cdot 16$ & $0.97 \pm 0.47$ & $0 \cdot 87 \pm 0.29$ & $0 \cdot 22 \pm 0 \cdot 11$ \\
\hline 12 & $0 \cdot 91 \pm 0 \cdot 46$ & $1 \cdot 13 \pm 0 \cdot 26$ & $1 \cdot 63 \pm 0 \cdot 50$ & $0 \cdot 86 \pm 0 \cdot 17$ & $0 \cdot 75 \pm 0 \cdot 19$ & $1 \cdot 33 \pm 0 \cdot 38$ & $1 \cdot 13 \pm 0 \cdot 26$ & $0 \cdot 71 \pm 0 \cdot 43$ & $0 \cdot 94 \pm 0 \cdot 32$ & $1.92 \pm 0.75$ & $3 \cdot 05 \pm 0 \cdot 69$ & $30 \cdot 43 \pm 8 \cdot 29$ & $25 \cdot 58 \pm 7 \cdot 19$ & $0 \cdot 59 \pm 0 \cdot 28$ \\
\hline 13 & $1 \cdot 02 \pm 0 \cdot 13$ & $1 \cdot 39 \pm 0 \cdot 32$ & $1 \cdot 77 \pm 0 \cdot 44$ & $1 \cdot 15 \pm 0 \cdot 38$ & $0 \cdot 80 \pm 0 \cdot 09$ & $2 \cdot 34 \pm 1 \cdot 13$ & $1 \cdot 22 \pm 0 \cdot 44$ & $0 \cdot 87 \pm 0 \cdot 54$ & $0 \cdot 99 \pm 0 \cdot 58$ & $0 \cdot 85 \pm 0 \cdot 26$ & $3 \cdot 56 \pm 0 \cdot 89$ & $18 \cdot 60 \pm 6 \cdot 75$ & $36 \cdot 70 \pm 10 \cdot 26$ & $0 \cdot 62 \pm 0 \cdot 25$ \\
\hline 14 & $0 \cdot 31 \pm 0 \cdot 13$ & $0 \cdot 43 \pm 0 \cdot 17$ & $0 \cdot 54 \pm 0 \cdot 13$ & $0 \cdot 32 \pm 0 \cdot 19$ & $0 \cdot 15 \pm 0.03$ & $2 \cdot 27 \pm 3 \cdot 57$ & $0 \cdot 18 \pm 0 \cdot 01$ & $0 \cdot 25 \pm 0 \cdot 13$ & $0 \cdot 33 \pm 0 \cdot 26$ & $0 \cdot 38 \pm 0 \cdot 10$ & $0 \cdot 41 \pm 0 \cdot 19$ & $0.53 \pm 0.47$ & $0 \cdot 62 \pm 0.19$ & $44 \cdot 45 \pm 3 \cdot 03$ \\
\hline 15 & $0 \cdot 26 \pm 0 \cdot 11$ & $0 \cdot 27 \pm 0 \cdot 08$ & $0 \cdot 54 \pm 0 \cdot 40$ & $0 \cdot 25 \pm 0 \cdot 13$ & $0.51 \pm 0.08$ & $0 \cdot 48 \pm 0.33$ & $0 \cdot 42 \pm 0.33$ & $0 \cdot 18 \pm 0 \cdot 08$ & $0 \cdot 33 \pm 0 \cdot 34$ & $0 \cdot 14 \pm 0 \cdot 09$ & $0 \cdot 44 \pm 0 \cdot 32$ & $0 \cdot 39 \pm 0.27$ & $0 \cdot 36 \pm 0 \cdot 17$ & $50 \cdot 73 \pm 2 \cdot 76$ \\
\hline 16 & $0 \cdot 23 \pm 0 \cdot 10$ & $0 \cdot 24 \pm 0 \cdot 17$ & $0 \cdot 23 \pm 0 \cdot 21$ & $0 \cdot 32 \pm 0 \cdot 10$ & $0 \cdot 19 \pm 0 \cdot 07$ & $2 \cdot 60 \pm 4 \cdot 61$ & $0 \cdot 15 \pm 0 \cdot 03$ & $0.09 \pm 0.09$ & $0 \cdot 36 \pm 0 \cdot 28$ & $0 \cdot 17 \pm 0 \cdot 07$ & $0 \cdot 53 \pm 0 \cdot 44$ & $0 \cdot 22 \pm 0 \cdot 21$ & $0 \cdot 28 \pm 0 \cdot 18$ & $0 \cdot 11 \pm 0 \cdot 04$ \\
\hline Total & 100 & 100 & 100 & 100 & 100 & 100 & 100 & 100 & 100 & 100 & 100 & 100 & 100 & 100 \\
\hline
\end{tabular}

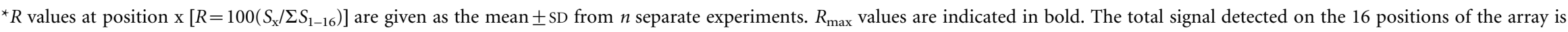
$100 \%$. 
ratio $(R)$ between the maximum-intensity signal of each individual spot $\left(S_{\mathrm{x}}\right)$ and the total signal from the 16 spots $\left(\Sigma S_{1}-S_{16}\right)$ and expressed as a percentage. All data in the text are $R$ values. Standardized data were calculated using the formula $R_{\mathrm{std}}=100\left(S_{\mathrm{x}}-S_{\min }\right) /\left(S_{\max }-S_{\min }\right)$, where $S_{\min }$ and $S_{\max }$ are respectively the minimum and maximum signal observed for an individual spot among all the spots present on the DNA macro-array. To avoid any confusion between classical DNA-DNA hybridization format (which is a true pairwise comparison where only two different DNAs are involved) and multiple DNA-DNA hybridization format on macro-arrays, we deliberately made the choice to display $R$, not $R_{\text {std. }}$ The usefulness of displaying one of these two parameters is discussed below. DNA macro-array hybridizations were repeated 4-10 times for a given labelled DNA. Values of Spearman's correlation coefficient $(r)$ were calculated to find relationships between hybridization patterns of macro-arrays. Microsoft Excel software was used for statistical calculations.

\section{Reproducibility}

A preliminary experiment was designed to assess the observed dispersion of $R$ values that could result from both the homogeneity of the DNA macro-arrays produced and the reproducibility through the entire procedure, from DNA hybridization to data integration. Ten aliquots corresponding to one-tenth of the labelled DNA of B. mallei ATCC $23344^{\mathrm{T}}(1 \mu \mathrm{g})$ were hybridized as described above, independently but simultaneously, to 10 different DNA macro-arrays originating from each of the 10 batches. This yielded 10 macro-array images, each containing 16 spots defined by a circular area of 304 pixels corresponding to the diameter of dots. The signal was extracted using the following parameters: volume, volume percentage and maximum pixel value. The maximum intensity level of 65524 counts per pixel was never reached. Each of the three types of parameter yielded the same results without significant variation of $R$ (data not shown). Maximum pixel value was used for subsequent calculations of $R$ and $R_{\mathrm{std}}$. For each position that refers to a given DNA spotted onto the macro-arrays, the arithmetic mean of $R$ and the standard deviation were: B. mallei ATCC $23344^{\mathrm{T}}, 27 \cdot 4 \pm 4 \cdot 0 \%$; B. pseudomallei ATCC $23343^{\mathrm{T}}, 15 \cdot 9 \pm 3 \cdot 8 \%$; B. multivorans LMG $13010^{\mathrm{T}}, 6 \cdot 8 \pm 0 \cdot 9 \%$; S. epidermidis, $0 \cdot 3 \pm 0 \cdot 1 \%$; no DNA, $0 \cdot 2 \pm 0 \cdot 1 \% \quad(n=10)$ (whole data not shown). Homogeneity of DNA macro-arrays hybridized to the DNA of B. mallei ATCC $23344^{\mathrm{T}}$ and experimental conditions yielded reproducible hybridization patterns $(r=0 \cdot 9541)$.

\section{Resolution}

The strains chosen for this study represent a portion of the variety of the genus Burkholderia (Table 1). To investigate the DNA-DNA relatedness of these strains, labelled DNA from each reference strain was hybridized individually to a DNA macro-array that allowed multiple nucleic acid hybridization. $R$ values were calculated to express the proportion of the signal measured from a spot, compared to the total signal measured for the 16 spots (Table 1). The unique $R_{\max }$ value measures the homologous DNA-DNA reassociation, and the 15 remaining $R$ values measure heterologous DNA-DNA reassociations. Consequently, $R_{\max }$ should decrease as the DNA-DNA relatedness among strains increases. As expected, $R_{\max }$ ranged from $81 \cdot 74 \%$ (Burkholderia glathei ATCC $29195^{\mathrm{T}}$ ) to $27 \cdot 89 \%$ (Burkholderia plantarii LMG $9035^{\mathrm{T}}$ ) for homologous pairs of DNAs. The higher $R_{\max }$ values observed for labelled DNA of Burkholderia caribensis LMG $18531^{\mathrm{T}}$, Burkholderia gladioli ATCC $10248^{\mathrm{T}}$ and B. glathei ATCC $29195^{\mathrm{T}}$ (respectively $79 \cdot 72,75 \cdot 77$ and $81 \cdot 74 \%$ ), coupled to the weakness of $R$ values for heterologous DNA pairing, may denote that these strains are distinct. Conversely, labelled DNA of other species yielded low $R_{\max }$ values $(27 \cdot 89-57 \cdot 66 \%)$, but nonnegligible $R$ values, as the probable result of crosshybridization of the probe to multiple positions on the array. The B. mallei ATCC $23344^{\mathrm{T}}$ probe yielded an $R_{\max }$ value of $30 \cdot 43 \pm 8 \cdot 29 \%$ (at the position of $B$. mallei) and markedly lower, an $R$ value of $18 \cdot 60 \pm 6 \cdot 75 \%$ at the position of B. pseudomallei ATCC $23343^{\mathrm{T}}$. Similarly, the probe for B. pseudomallei ATCC $23343^{\mathrm{T}}$ yielded an $R_{\max }$ value of $36 \cdot 70 \pm 10 \cdot 26 \%$ (at the position of B. pseudomallei) and markedly lower, an $R$ value of $25 \cdot 58 \pm 7 \cdot 19 \%$ at the position of B. mallei ATCC $23344^{\mathrm{T}}$. It is known that B. mallei and B. pseudomallei are closely related, to the extent that published DNA-DNA relatedness values, obtained by the classical fluorimetric method in microdilution wells, are higher than $90 \%$ (Yabuuchi et al., 1992). However, the distinction between these two species is justified, based on pathogenicity. Originally included in the study design, Burkholderia thailandensis ATCC $700388^{\mathrm{T}}$ was not available when the work started. It is reasonable to assume that labelled DNA from B. thailandensis ATCC $700388^{\mathrm{T}}$ would have hybridized strongly to itself, to a lower extent to B. mallei and B. pseudomallei, and to a non-negligible extent to the members of the B. cepacia complex.

The symmetry of $R$ values between $B$. mallei and B. pseudomallei was further investigated by determining $R$ values with labelled DNA from two additional strains of B. mallei and 12 strains of B. pseudomallei (Table 2). The hybridization patterns observed for the three different strains of $B$. mallei are homogeneous $(r=0.9578)$ and consistent with that of B. mallei ATCC $23344^{\mathrm{T}}(n=10)$. The $R$ values observed for positions of B. mallei ATCC $23344^{\mathrm{T}}$ and B. pseudomallei ATCC $23343^{\mathrm{T}}$ are not significantly different, but both differ significantly from $R$ values observed at other positions (i.e. other Burkholderia species). The hybridization patterns observed for the 12 different strains of B. pseudomallei are more homogeneous ( $r=$ 0.9781 ). Moreover, significant differences of $R$ values are observed for positions of B. mallei ATCC $23344^{\mathrm{T}}$ and B. pseudomallei ATCC $23343^{\mathrm{T}}$ on the array. For labelled DNA from both B. mallei and B. pseudomallei, the hybridization profiles at the remaining positions were similar. The $R$ values are high for B. cepacia genomovar I 
Table 2. Dispersion of $R$ values observed with labelled DNA from three different strains of $B$. mallei and 12 different strains of $B$. pseudomallei

In addition to the type strains of B. mallei and B. pseudomallei, the following strains were tested: B. mallei CIP A192 and CIP A193 (obtained from the Collection de l'Institut Pasteur, Paris, France); B. pseudomallei CIP 58-52-238, CIP 58-56-91, CIP 59-62-28, CIP 60-68-3 (obtained from the CIP), CRSSA 14/97 and 29/97 (formerly ATCC 11668 and ATCC 15682, respectively), 8/93, 41/97, 42/97, 43/97 and 47/97 (obtained from Centre de Recherche du Service de Santé des Armées, La Tronche, France). Each strain was tested once.

\begin{tabular}{|lcc|}
\hline \multirow{2}{*}{ DNA on arrays* } & \multicolumn{2}{c|}{$\boldsymbol{R}(\%)$ with labelled DNA from: } \\
\cline { 2 - 3 } & $\boldsymbol{B} \cdot$ mallei $(\boldsymbol{n}=\mathbf{3})$ & $\boldsymbol{B} \cdot$ pseudomallei $(\boldsymbol{n}=\mathbf{1 2})$ \\
\hline 1 & $7 \cdot 3 \pm 0 \cdot 9$ & $7 \cdot 4 \pm 1 \cdot 2$ \\
2 & $7 \cdot 3 \pm 1 \cdot 9$ & $9 \cdot 2 \pm 1 \cdot 6$ \\
3 & $8 \cdot 4 \pm 1 \cdot 1$ & $8 \cdot 4 \pm 1 \cdot 2$ \\
4 & $3 \cdot 3 \pm 0 \cdot 5$ & $3 \cdot 4 \pm 0 \cdot 4$ \\
5 & $5 \cdot 5 \pm 0 \cdot 9$ & $5 \cdot 4 \pm 0 \cdot 8$ \\
6 & $8 \cdot 2 \pm 0 \cdot 3$ & $6 \cdot 5 \pm 0 \cdot 5$ \\
7 & $4 \cdot 3 \pm 1 \cdot 4$ & $6 \cdot 3 \pm 0 \cdot 8$ \\
8 & $3 \cdot 5 \pm 1 \cdot 7$ & $4 \cdot 2 \pm 1 \cdot 0$ \\
9 & $3 \cdot 3 \pm 1 \cdot 1$ & $4 \cdot 4 \pm 0 \cdot 7$ \\
10 & $4 \cdot 0 \pm 1 \cdot 8$ & $4 \cdot 1 \pm 0 \cdot 7$ \\
11 & $1 \cdot 5 \pm 0 \cdot 6$ & $1 \cdot 5 \pm 0 \cdot 4$ \\
12 & $22 \cdot 3 \pm 5 \cdot 9$ & $15 \cdot 1 \pm 2 \cdot 7$ \\
13 & $20 \cdot 3 \pm 5 \cdot 4$ & $23 \cdot 4 \pm 4 \cdot 7$ \\
14 & $0 \cdot 3 \pm 0 \cdot 2$ & $0 \cdot 3 \pm 0 \cdot 2$ \\
15 & $0 \cdot 2 \pm 0 \cdot 1$ & $0 \cdot 2 \pm 0 \cdot 1$ \\
16 & $0 \cdot 3 \pm 0 \cdot 1$ & $0 \cdot 1 \pm 0 \cdot 1$ \\
Total & 100 & 100 \\
\hline
\end{tabular}

${ }^{\star}$ See legend to Table 1 for strains.

ATCC $25416^{\mathrm{T}}$, B. cepacia genomovar III LMG 12614 , B. multivorans LMG $13010^{\mathrm{T}}$, Burkholderia pyrrocinia ATCC $15958^{\mathrm{T}}$, Burkholderia stabilis LMG $14294^{\mathrm{T}}$, Burkholderia vietnamiensis $\mathrm{LMG} 10929^{\mathrm{T}}$ and Burkholderia sp. isolate CEB 01056, and low at other positions. One could have expected that these cross-hybridizations should have yielded reciprocal values (by a significant increase of $R$ at positions of B. mallei and B. pseudomallei) when using labelled DNA from the species $B$. cepacia genomovar I ATCC $25416^{\mathrm{T}}$, B. cepacia genomovar III LMG 12614, B. multivorans LMG $13010^{\mathrm{T}}$, B. pyrrocinia ATCC $15958^{\mathrm{T}}$, B. stabilis LMG $14294^{\mathrm{T}}$, B. vietnamiensis LMG $10929^{\mathrm{T}}$ and Burkholderia sp. isolate CEB 01056. Curiously, this was not the case, thus generating asymmetrical sections of the matrix (Table 1). This was also observed for B. plantarii LMG $9035^{\mathrm{T}}$. The genome of B. cepacia ATCC $25416^{\mathrm{T}}$ (Rodley et al., 1995) and that of Burkholderia fungorum LB400 (Joint Genome Institute, http://www.jgi.doe.gov), both estimated at $8 \cdot 1 \mathrm{Mb}$, are markedly larger than those of $B$. pseudomallei clinical isolate K96943, estimated at $6.5 \mathrm{Mb}$ (Songsivilai \& Dharakul, 2000) and B. mallei ATCC $23344^{\mathrm{T}}$, estimated at $6.0 \mathrm{Mb}$ (The
Institute for Genomic Research, http://www.tigr.org). The homologous hybridizing proportion of the larger genomes will thus be correspondingly smaller than that of the smaller genomes, and may result in non-reciprocity. Such nonsymmetry of matrices has already been observed for classical DNA-DNA homology studies (Lisdiyanti et al., 2002; Takeuchi \& Hatano, 1998).

The B. cepacia complex strains tested (genomovars I, II, III, IV and V), B. pyrrocinia ATCC $15958^{\mathrm{T}}$ and the isolate CEB 01056 of Burkholderia sp. constitute a distinct DNA homology subgroup (Table 1): $40 \cdot 12 \%<R_{\max }<57 \cdot 66 \%$, $3.69 \%<R<12.29 \%$ within this subgroup (mean $7.06 \pm$ $2.31 \%$ ), $R<2.52 \%$ with other species (mean $0.99 \pm$ $0.65 \%)$. All these type strains are fully differentiated. This does not prejudge about the differentiation of $B$. cepacia members other than those tested herein.

DNA homology values relevant to the strains used herein have been obtained previously (Achouak et al., 1999; Coenye et al., 1999; Vandamme et al., 1997; Viallard et al., 1998; Yabuuchi et al., 1992) based on three different techniques: nuclease S1 (NS1), microfluorimetry (MF) and spectrophotometry (SP) (Fig. 1). These data and current $R$ values were plotted and a linear regression curve was then calculated (Fig. 1). The $r^{2}$ value of 0.740 demonstrates a weak positive correlation between DNA homology measures obtained by two radically different approaches. The slope of the tendency curve is therefore greatly affected by the value of $R$ at $100 \%$ DNA-DNA relatedness, because $R_{\max }$ values are directly lowered by the extent of cross-hybridization at other positions on the array. The use of the standardized ratio $R_{\text {std }}$ eliminates this bias, thus strengthening the correlation $\left(r^{2}=0 \cdot 904\right)$. The correlation between the NS1, MF, SP and macro-array methods by comparing DNA similarity values for several DNA pairs remains to be assessed. Presently available data are rare but encouraging, and highlight the asymmetry mentioned above (Table 3). The qualitative (e.g. diversity of species) and quantitative (e.g. number of species) nature of the genetic material spotted on the array remains to be addressed, to determine how it affects $R$ values.

B. mallei and B. pseudomallei are discriminated by PCR on the basis of a single nucleotide difference in the $23 \mathrm{~S}$ rDNA sequence (Bauernfeind et al., 1998). The ongoing identification of virulence determinants by subtractive hybridization will provide new tools in specific detection of these two species (DeShazer et al., 2001). Proposition of B. thailandensis (Brett et al., 1998), formerly a Burkholderia pseudomallei-like species that is able to assimilate L-arabinose contrary to $B$. pseudomallei, has been reinforced by $16 \mathrm{~S}$ rDNA sequence analysis of numerous $\mathrm{Ara}^{+}$or $\mathrm{Ara}^{-}$clinical and environmental isolates (Dharakul et al., 1999). Differentiation of Burkholderia species, most particularly those belonging to the $B$. cepacia complex, has been intensively addressed in the last few years, and a combination of phenotypic and molecular tests such as recA PCR and $16 \mathrm{~S}$ rDNA RFLP are recommended for 


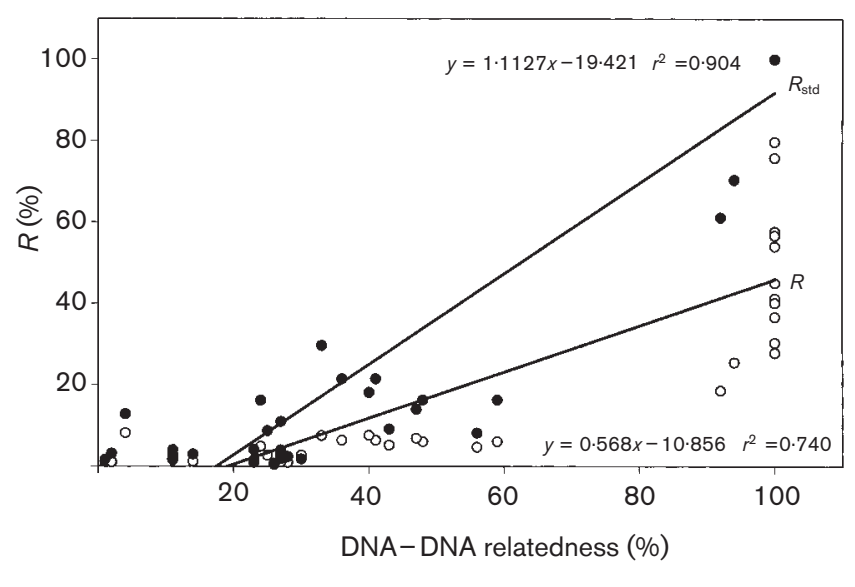

Fig. 1. Relationship between previously reported DNA-DNA relatedness values (references in the text) and $R$ (open circles) or $R_{\text {std }}$ (filled circles) values, obtained by the DNA macro-array method.

differentiation among the genomovars; the reliability of these approaches has been reviewed recently (Speert et al., 2002). All these methods target different cellular constituents and are thus complementary; however, none of them consider the whole genome. Delineation of four Pseudomonas species by DNA-DNA hybridization, which uses hundreds of genome fragments of each species spotted onto DNA micro-arrays, offsets laborious cross-hybridization but needs tedious cloning and handling of genome fragments (Cho \& Tiedje, 2001). The overall homology between two genomes remains an important feature in the identification process for atypical isolates or species never encountered before. The sequencing of complete genomes has opened the way for micro-arraying nearly all ORFs of a bacterium, and for future evaluation of whole-genome homology in a geneby-gene manner (Dziejman et al., 2002; Schoolnik, 2002).

DNA-DNA hybridization using genomic DNA macroarrays looks like an interesting tool at the species level, and should be thoroughly addressed at the subspecies level by investigating several clinical and environmental isolates. Low intraspecies DNA-DNA hybridization values (up to
$54 \%$ ) have been reported in several members of the B. cepacia complex, especially for genomovars I and III (Vandamme et al., 1997). Moreover, comparison of data in Tables 1 and 2 suggests that $R$ values (at the B. mallei and B. pseudomallei positions) tend to overlap more as the number of strains examined increases. This suggests a low clonality of the population structure that could be a result of 'rampant interspecific recombination' (Ochman et al., 2000).

DNA-DNA hybridization using genomic DNA macroarrays is simple and constitutes a straightforward approach for species identification. Automation of arraying enables the production of large quantities of macro-arrays, and the most demanding efforts consist of preparing the reference DNA stocks from type strains and updating macro-arrays for their species content as novel species are described. Once available, these macro-arrays could be used to investigate the nature of numerous unknown labelled DNAs extracted from various sources. There are at least two potential applications in whole-genome-based bacterial identification, as an initial step preceding the use of more appropriate or targeted tests. The first is the species identification of a large number of strains isolated from clinical infection or recovered from natural environments. Identification and monitoring of bacteria by reverse sample genome probing (RSGP) has already been described, for example in soil (Léveillé et al., 2001; Shen et al., 1998). The second application concerns the monitoring of bacteria in the environment by RSGP and a possible way to analyse spatio-temporal variations in bacterial communities within a biotope. DNA-DNA hybridization using genomic DNA macro-array analysis may be modified to use non-radioactive labelling and thus become a high-throughput alternative for existing DNADNA hybridization methods.

\section{Acknowledgements}

We would like to thank M. A. Labarre and I. Rébillat for maintaining cultures, C. Simoes for DNA extraction, and J. Chatoux and C. Pannetier who made sequencing facilities available. This work was funded by Délégation Générale pour l'Armement through grants PEA983601 and PEA983602 related to bio-defence.

Table 3. Comparison of DNA similarity values obtained by various methods

Methods used were nuclease S1 (NS1) (Viallard et al., 1998), microfluorimetry (MF) (Yabuuchi et al., 1992), spectrophotometry (SP) (Vandamme et al., 1997) and macro-arrays (MA), with labelled DNA of B. cepacia (I) ATCC $25416^{\mathrm{T}}$. NA, Not available.

\begin{tabular}{|lcccr|r|}
\hline \multirow{2}{*}{ Strain } & \multicolumn{4}{c|}{ DNA similarity (\%) with labelled DNA from B. cepacia ATCC 25416 } \\
\cline { 2 - 5 } & NS1 & MF & SP & MA $^{\text {T }}$ \\
\hline B. gladioli ATCC $10248^{\mathrm{T}}$ & 27 & 23 & 11 & $1 \cdot 56 \pm 0 \cdot 53$ & $2 \cdot 72 \pm 1 \cdot 15$ \\
B. pyrrocinia ATCC $15958^{\mathrm{T}}$ & 48 & NA & 59 & $6 \cdot 07 \pm 1 \cdot 89$ & $14 \cdot 63 \pm 4 \cdot 16$ \\
B. vietnamiensis (V) LMG $10929^{\mathrm{T}}$ & 41 & NA & 36 & $6 \cdot 40 \pm 1 \cdot 96$ \\
\hline
\end{tabular}

${ }^{\star} \mathrm{MA}_{\text {rev }}$ indicates the reverse labelling situation. 


\section{References}

Achouak, W., Christen, R., Barakat, M., Martel, M.-H. \& Heulin, T. (1999). Burkholderia caribensis sp. nov., an exopolysaccharideproducing bacterium isolated from vertisol microaggregates in Martinique. Int J Syst Bacteriol 49, 787-794.

Balandreau, J., Viallard, V., Cournoyer, B., Coenye, T., Laevens, S. \& Vandamme, P. (2001). Burkholderia cepacia genomovar III is a common plant-associated bacterium. Appl Environ Microbiol 67, 982-985.

Bauernfeind, A., Roller, C., Meyer, D., Jungwirth, R. \& Schneider, I. (1998). Molecular procedure for rapid detection of Burkholderia mallei and Burkholderia pseudomallei. J Clin Microbiol 36, 2737-2741.

Benenson, A. S. (1995). Control of Communicable Diseases Manual, 6th edn, pp. 335-338. Washington, DC: American Public Health Association.

Brett, P. J., DeShazer, D. \& Woods, D. E. (1998). Burkholderia thailandensis sp. nov., a Burkholderia pseudomallei-like species. Int J Syst Bacteriol 48, 317-320.

Brisse, S., Verduin, C. M., Milatovic, D. \& 7 other authors (2000). Distinguishing species of the Burkholderia cepacia complex and Burkholderia gladioli by automated ribotyping. J Clin Microbiol 38, 1876-1884.

Cho, J.-C. \& Tiedje, J. M. (2001). Bacterial species determination from DNA-DNA hybridization by using genome fragments and DNA microarrays. Appl Environ Microbiol 67, 3677-3682.

Coenye, T., Holmes, B., Kersters, K., Govan, J. R. W. \& Vandamme, P. (1999). Burkholderia cocovenenans (van Damme et al. 1960) Gillis et al. 1995 and Burkholderia vandii Urakami et al. 1994 are junior synonyms of Burkholderia gladioli (Severini 1913) Yabuuchi et al. 1993 and Burkholderia plantarii (Azegami et al. 1987) Urakami et al. 1994, respectively. Int J Syst Bacteriol 49, 37-42.

Coenye, T., LiPuma, J. J., Henry, D., Hoste, B., Vandemeulebroecke, K., Gillis, M., Speert, D. P. \& Vandamme, P. (2001a). Burkholderia cepacia genomovar VI, a new member of the Burkholderia cepacia complex isolated from cystic fibrosis patients. Int J Syst Evol Microbiol 51, 271-279.

Coenye, T., Mahenthiralingam, E., Henry, D., LiPuma, J. J., Laevens, S., Gillis, M., Speert, D. P. \& Vandamme, P. (2001b). Burkholderia ambifaria sp. nov., a novel member of the Burkholderia cepacia complex including biocontrol and cystic fibrosis-related isolates. Int J Syst Evol Microbiol 51, 1481-1490.

Coenye, T., Vandamme, P., Govan, J. R. W. \& LiPuma, J. J. (2001c). Taxonomy and identification of the Burkholderia cepacia complex. J Clin Microbiol 39, 3427-3436.

Dance, D. A. (2002). Melioidosis. Curr Opin Infect Dis 15, 127-132. DeShazer, D., Waag, D. M., Fritz, D. L. \& Woods, D. E. (2001). Identification of a Burkholderia mallei polysaccharide gene cluster by subtractive hybridization and demonstration that the encoded capsule is an essential virulence determinant. Microb Pathog 30, 253-269.

Dharakul, T., Tassaneetrithep, B., Trakulsomboon, S. \& Songsivilai, S. (1999). Phylogenetic analysis of $\mathrm{Ara}^{+}$and $\mathrm{Ara}^{-}$Burkholderia pseudomallei isolates and development of a multiplex PCR procedure for rapid discrimination between the two biotypes. J Clin Microbiol 37, 1906-1912.

Dziejman, M., Balon, E., Boyd, D., Fraser, C. M., Heidelberg, J. F. \& Mekalanos, J. J. (2002). Comparative genomic analysis of Vibrio cholerae: genes that correlate with cholera endemic and pandemic disease. Proc Natl Acad Sci U S A 99, 1556-1561.

Gilligan, P. H. (1995). Pseudomonas and Burkholderia. In Manual of Clinical Microbiology, 6th edn, pp. 509-519. Edited by P. R. Murray,
E. J. Baron, M. A. Pfaller, F. C. Tenover \& R. H. Yolken. Washington, DC: American Society for Microbiology.

Heath, D. G., Hohneker, K., Carriker, C., Smith, K., Routh, J., LiPuma, J. J., Aris, R. M., Weber, D. \& Gilligan, P. H. (2002). Six-year molecular analysis of Burkholderia cepacia complex isolates among cystic fibrosis patients at a referral center for lung transplantation. J Clin Microbiol 40, 1188-1193.

Henry, D. A., Mahenthiralingam, E., Vandamme, P., Coenye, T. \& Speert, D. P. (2001). Phenotypic methods for determining genomovar status of the Burkholderia cepacia complex. J Clin Microbiol 39, 1073-1078.

Holmes, A., Govan, J. \& Goldstein, R. (1998). Agricultural use of Burkholderia (Pseudomonas) cepacia: a threat to human health? Emerg Infect Dis 4, 221-227.

Inglis, T. J. J., Rigby, P., Robertson, T. A., Dutton, N. S., Henderson, M. \& Chang, B. J. (2000). Interaction between Burkholderia pseudomallei and Acanthamoeba species results in coiling phagocytosis, endamebic bacterial survival, and escape. Infect Immun 68, 1681-1686.

Johnson, J. L. (1991). DNA reassociation experiments. In Nucleic Acid Techniques in Bacterial Systematics, pp. 21-44. Edited by E. Stackebrandt \& M. Goodfellow. Chichester: Wiley.

Jones, A. M., Dodd, M. E. \& Webb, A. K. (2001). Burkholderia cepacia: current clinical issues, environmental controversies and ethical dilemmas. Eur Respir J 17, 295-301.

Léveillé, S. A., Leduc, L. G., Ferroni, G. D., Telang, A. J. \& Voordouw, G. (2001). Monitoring of bacteria in acid mine environments by reverse sample genome probing. Can J Microbiol 47, 431-442.

LiPuma, J. J., Spilker, T., Coenye, T. \& Gonzalez, C. F. (2002). An epidemic Burkholderia cepacia complex strain identified in soil. Lancet 359, 2002-2003.

Lisdiyanti, P., Kawasaki, H., Widyastuti, Y., Saono, S., Seki, T., Yamada, Y., Uchimura, T. \& Komagata, K. (2002). Kozakia baliensis gen. nov., sp. nov., a novel acetic acid bacterium in the $\alpha$ Proteobacteria. Int J Syst Evol Microbiol 52, 813-818.

Mahenthiralingam, E., Bischof, J., Byrne, S. K., Radomski, C., Davies, J. E., Av-Gay, Y. \& Vandamme, P. (2000). DNA-based diagnostic approaches for identification of Burkholderia cepacia complex, Burkholderia vietnamiensis, Burkholderia multivorans, Burkholderia stabilis, and Burkholderia cepacia genomovars I and III. J Clin Microbiol 38, 3165-3173.

Mougel, C., Thioulouse, J., Perrière, G. \& Nesme, X. (2002). A mathematical method for determining genome divergence and species delineation using AFLP. Int J Syst Evol Microbiol 52, 573-586.

Ochman, H., Lawrence, J. G. \& Groisman, E. A. (2000). Lateral gene transfer and the nature of bacterial innovation. Nature 405, 299-304.

Parke, J. L. \& Gurian-Sherman, D. (2001). Diversity of the Burkholderia cepacia complex and implications for risk assessment of biological control strains. Annu Rev Phytopathol 39, 225-258.

Rajan, S. \& Saiman, L. (2002). Pulmonary infections in patients with cystic fibrosis. Semin Respir Infect 17, 47-56.

Rodley, P. D., Romling, U. \& Tummler, B. (1995). A physical genome map of the Burkholderia cepacia type strain. Mol Microbiol 17, 57-67.

Rosselló-Mora, R. \& Amann, R. (2001). The species concept for prokaryotes. FEMS Microbiol Rev 25, 39-67.

Rotz, L. D., Khan, A. S., Lillibridge, S. R., Ostroff, S. M. \& Hughes, J. M. (2002). Public health assessment of potential biological terrorism agents. Emerg Infect Dis 8, 225-230.

Schoolnik, G. K. (2002). Functional and comparative genomics of pathogenic bacteria. Curr Opin Microbiol 5, 20-26.

Segonds, C., Heulin, T., Marty, N. \& Chabanon, G. (1999). Differentiation of Burkholderia species by PCR-restriction fragment 
length polymorphism analysis of the 16S rRNA gene and application to cystic fibrosis isolates. J Clin Microbiol 37, 2201-2208.

Shen, Y., Stehmeier, L. G. \& Voordouw, G. (1998). Identification of hydrocarbon-degrading bacteria in soil by reverse sample genome probing. Appl Environ Microbiol 64, 637-645.

Songsivilai, S. \& Dharakul, T. (2000). Multiple replicons constitute the 6.5-megabase genome of Burkholderia pseudomallei. Acta Trop 74, 169-179.

Speert, D. P., Henry, D., Vandamme, P., Corey, M. \& Mahenthiralingam, E. (2002). Epidemiology of Burkholderia cepacia complex in patients with cystic fibrosis, Canada. Emerg Infect Dis 8, 181-187.

Srinivasan, A., Kraus, C. N., DeShazer, D., Becker, P. M., Dick, J. D., Spacek, L., Bartlett, J. G., Byrne, W. R. \& Thomas, D. L. (2001). Glanders in a military research microbiologist. $N$ Engl J Med 345, 256-258.

Stackebrandt, E., Frederiksen, W., Garrity, G. M. \& 10 other authors (2002). Report of the ad hoc committee for the re-evaluation of the species definition in bacteriology. Int J Syst Evol Microbiol 52, 1043-1047.

Steinmetz, I., Reganzerowski, A., Brenneke, B., Häussler, S., Simpson, A. \& White, N. J. (1999). Rapid identification of Burkholderia pseudomallei by latex agglutination based on an exopolysaccharidespecific monoclonal antibody. J Clin Microbiol 37, 225-228.

Takeuchi, M. \& Hatano, K. (1998). Proposal of six new species in the genus Microbacterium and transfer of Flavobacterium marinotypicum ZoBell and Upham to the genus Microbacterium as Microbacterium maritypicum comb. nov. Int J Syst Bacteriol 48, 973-982.

Vandamme, P., Pot, B., Gillis, M., de Vos, P., Kersters, K. \& Swings, J. (1996). Polyphasic taxonomy, a consensus approach to bacterial systematics. Microbiol Rev 60, 407-438.
Vandamme, P., Holmes, B., Vancanneyt, M. \& 8 other authors (1997). Occurrence of multiple genomovars of Burkholderia cepacia in cystic fibrosis patients and proposal of Burkholderia multivorans sp. nov. Int J Syst Bacteriol 47, 1188-1200.

Vandamme, P., Mahenthiralingam, E., Holmes, B., Coenye, T., Hoste, B., De Vos, P., Henry, D. \& Speert, D. P. (2000). Identification and population structure of Burkholderia stabilis sp. nov. (formerly Burkholderia cepacia genomovar IV). J Clin Microbiol 38, 1042-1047.

Vandamme, P., Henry, D., Coenye, T., Nzula, S., Vancanneyt, M., LiPuma, J. J., Speert, D. P., Govan, J. R. W. \& Mahenthiralingam, E. (2002). Burkholderia anthina sp. nov. and Burkholderia pyrrocinia, two additional Burkholderia cepacia complex bacteria, may confound results of new molecular diagnostic tools. FEMS Immunol Med Microbiol 33, 143-149.

Viallard, V., Poirier, I., Cournoyer, B., Haurat, J., Wiebkin, S., OphelKeller, K. \& Balandreau, J. (1998). Burkholderia graminis sp. nov., a rhizospheric Burkholderia species, and reassessment of [Pseudomonas] phenazinium, [Pseudomonas] pyrrocinia and [Pseudomonas] glathei as Burkholderia. Int J Syst Bacteriol 48, 549-563.

Wayne, L. G., Brenner, D. J., Colwell, R. R. \& 9 other authors (1987). International Committee on Systematic Bacteriology. Report of the ad hoc committee on reconciliation of approach to bacterial systematics. Int J Syst Bacteriol 37, 463-464.

Yabuuchi, E., Kosako, Y., Oyaizu, H., Yano, I., Hotta, H., Hashimoto, Y., Ezaki, T. \& Arakawa, M. (1992). Proposal of Burkholderia gen. nov. and transfer of seven species of the genus Pseudomonas homology group II to the new genus, with the type species Burkholderia cepacia (Palleroni and Holmes 1981) comb. nov. Microbiol Immunol 36, 1251-1275. 